\title{
STUDI INTEGRASI WISATA RELIGIUS DAN WISATA BAHARI (OBJEK STUDI: KAWASAN BANTEN LAMA DAN PELABUHAN KARANGANTU)
}

\author{
Rizky Adhitya Pradani ${ }^{11}$, Suryono Herlambang ${ }^{2)}$, Suryadi Santoso ${ }^{3)}$ \\ 1)Program Studi S1 PWK, Fakultas Teknik, Universitas Tarumanagara, rizkyapradani03@gmail.com \\ 2)Program Studi S1 PWK, Fakultas Teknik, Universitas Tarumanagara, s.herlambang@gmail.com \\ 3)Program Studi S1 PWK, Fakultas Teknik, Universitas Tarumanagara, josantosojkt@yahoo.com
}

Masuk: 12-08-2020, revisi: 28-09-2020, diterima untuk diterbitkan: 29-09-2020

\begin{abstract}
Abstrak
Kawasan Banten Lama dan Pelabuhan Karangantu terletak di Kecamatan Kasemen, Kota Serang dan merupakan bekas peninggalan Kesultanan Banten di Pulau Jawa. Dahulu Kawasan ini menjadi pusat peradaban dan perdagangan internasional di Pulau Jawa. Kawasan Banten Lama sendiri saat ini menjadi daya tarik wisata utama di Kota Serang dengan adanya Masjid Agung Banten yang menjadi destinasi Wisata Religi di Kota Serang. Bahkan pada tahun 2017, jumlah Wisatawan yang berkunjung ke Masjid Agung Banten mencapai 1,7 Juta orang. Berbeda nasibnya dengan Kawasan Pelabuhan Karangantu yang saat ini tidak berkembang sepesat Banten Lama. Padahal Pelabuhan Karangantu sendiri memiliki potensi wisata bahari dengan hasil alamnya dan akses ke objek wisata bahari di sekitarnya. Walaupun adanya keterkaitan sejarah antara Banten Lama dan Pelabuhan karangantu namun saat ini terjadi ketimpangan perkembangan antar kedua objek ini, dimana daerah Banten Lama jauh lebih berkembang daripada Pelabuhan Karangantu. Tujuan penelitian ini adalah untuk memberikan usulan faktor-faktor yang dapat di integrasikan dari Wisata Reliji di Banten Lama dan Wisata Bahari di Pelabuhan Karangantu. Menggunakan metodologi deskriptif kualititatif. Analisis yang digunakan yaitu analisis kebijakan, analisis lokasi dan tapak, analisis nilai sejarah, analisis daya tarik wisata, analisis integrasi wisata. Hasil dari analisis ini adalah ditemukannya dua unsur yang dapat dipadukan untuk Pariwisata Banten Lama dan Karangantu yang lebih terpadu yaitu aksesibilitas antar objek wisata dan suasana.antar objek wisata.
\end{abstract}

Kata kunci: Banten Lama; integrasi wisata; wisata bahari; wisata religi; Pelabuhan Karangantu

\begin{abstract}
The Old Banten City and Port of Karangantu are located in Kasemen District, Serang City and are the remnants of the Sultanate of Banten in Java. This area was once the center of civilization and international trade in Java. The Old Banten City itself is currently the main tourist attraction in the City of Serang with the Banten Grand Mosque being the religious tourism destination in the City of Serang. In 2017, the number of tourists visiting the Banten Grand Mosque reached 1.7 million people. Its fate is vastly different from the Port of Karangantu which is currently not well developed as The Old Banten City. Whereas Karangantu itself has the potential for marine tourism with its natural products and access to marine tourism objects in the vicinity. Although there is a historical link between Banten Lama and Port of Karangantu, there is currently a developmental imbalance between the two objects, where the Old Banten City is much more developed than Karangantu Harbor. The purpose of this study is to propose any aspects that can be integrated from Religious Tourism in Banten Lama and Maritime Tourism in Port of Karangantu. This Research use qualitative descriptive methodology. The analysis used is policy analysis, location and site analysis, historical value analysis, tourist attraction analysis, tourism integration analysis. The results of this analysis are the discovery of two aspects that can be integrated for Tourism in The Old Banten City and Karangantu, namely accessibility and atmosphere between The Old Banten City and Karangantu.
\end{abstract}

Keywords: integrated tourism; maritime tourism; Old Banten City; Port of Karangantu; religious tourism 


\section{PENDAHULUAN}

\section{Latar Belakang}

Diantara banyaknya daya tarik wisata cagar budaya di Provinsi Banten, Kota Banten Lama menjadi penarik wisatawan paling besar di Provinsi Banten. Kota Banten Lama dahulu kala pernah menjadi wilayah salah satu kesultanan paling berpengaruh di Indonesia pada abad ke-16. Kota ini dikenal sebagai salah satu kota pelabuhan paling signifikan di tanah Jawa selama fase sejarah ketiga, ketika Islam memerintah, sampai masa kolonialisme Belanda. Kota ini membawa Kesultanan Banten menjadi salah satu kerajaan paling kuat yang melawan kolonialisme dan salah satu kekuatan politik dan ekonomi paling signifikan di tanah Jawa sebelum Republik Indonesia dibentuk. Sayangnya kejayaanya berakhir dengan jatuhnya Kota Banten Lama ke tangan pemerintah kolonial Belanda. Situs bersejarah ini memiliki sisa beberapa bangunan, benteng, dan reruntuhan yang tersebar di area seluas 10 ha dan sekarang menjadi Kawasan Warisan Budaya nasional yang diakui.

Di dalam Kota Tua Banten Lama, terdapat beberapa objek bersejarah yaitu Masjid Agung Banten, Situs Istana Surosowan, Benteng Speljwick, Keraton Kaibon Masjid Pecinan, Vihara Avalokitesvara dan Pelabuhan Karangantu. Diantara objek-objek bersejarah tersebut, Masjid Agung Banten dan Istana Surosowan menjadi ikon dan penarik terbesar pariwisata di Kota Banten Lama.

Masjid Agung Banten adalah salah satu masjid tertua yang ada di Indonesia. Masjid ini merupakan masjid pusat penyebaran agama Islam di Banten. Masjid Agung Banten dibangun pertama kali oleh Sultan Hasanuddin pada abad ke 16 . Selain nilai sejarah dan nilai reliji didalamnya, Masjid ini juga mempunyai nilai keunikan di gaya arsitekturnya yang mencampurkan gaya bangunan Jawa dengan Cina dan Belanda. Menurut Kepala Bidang Promosi Pariwisata DISPARPORA Kota Serang, Jumlah wisatawan ke Masjid Agung Banten pada tahun 2017 mencapai 1,7 Juta pengunjung . Pengunjung yang berkunjung ke Masjid Agung Banten sebagian besar untuk melakukan wisata religi dengan berziarah ke Makam keluarga Sultan Hasanuddin.

Tepat di dekat Masjid Agung Banten, berdiri Istana Surosowan yang dahulu kala menjadi tempat tinggal sultan-sultan dari Kesultanan Banten. Istana Surosowan dibangun pada masa yang sama dengan Masjid Agung Banten yaitu pada masa kekuasaan Sultan Hasanuddin. Istana Surosowan saat ini hanya tersisa pung-puing bangunan dan tembok dari Benteng yang melindunginya. Di Istana Surosowan juga terdapat kolam taman Roro Denok yang airnya berasal dari Danau Tasikardi.

Melihat tingginya kunjungan wisatawan Ke Kota Banten Lama, Pemerintah Daerah Provinsi Banten pada tahun 2018 mulai merealisasikan Rencana Revitalisasi Banten Lama. Rencana untuk Revitalisasi Banten Lama sebenarnya sudah direncanakan sejak pertama kali Provinsi Banten berdiri tetapi baru mulai dikaji pada tahun 2015. Didalam program Revitalisasi Banten Lama ini, hampir seluruh objekobjek bersejarah di Kota Banten Lama termasuk kedalamnya kecuali Pelabuhan Karangantu.

Pelabuhan Karangantu di masa kejayaanya berperan besar sebagai pintu masuk perdagangan internasional di Pulau Jawa. Setelah runtuhnya Kota Banten Lama, Pelabuhan ini sempat dilupakan hingga akhirnya beralih fungsi menjadi pusat dagang perikanan dan penyebrangan. Seiring dengan pudarnya nilai sejarah di pelabuhan ini, kondisi fisik sekitar pelabuhan menurun hingga menjadi kumuh dan aroma tidak sedap datamg dari limbah perdagangan ikan. Padahal Pelabuhan Karangantu menyimpan banyak potensi wisata dengan kekayaan sumber daya perikanan yang dimiliki, hutan bakau yang terhampar luas dan pulau-pulau yang terdapat di sekitar pelabuhan seperti Pulau Tunda dan Pulau Cangkir yang dapat dijadikan tujuan wisata.

Pelabuhan Karangantu sendiri saat ini sudah diakui oleh Pemerintah Kota Serang menjadi salah satu objek pariwisata di Kota Serang. Ini terbukti dengan dimasukkannya Pelabuhan Karangantu ke dalam Rencana Tata Ruang Wilayah Kota Serang Tahun 2011 dan Rencana Induk Kepariwisataan Daerah 
(RIPPDA) Kota Serang tahun 2015. Di dalam kedua rencana ini, Pelabuhan Karangantu termasuk kedalam Program Pemerintah Kota Serang dalam Mengembangkan Pariwisata Cagar Budaya di Kota Serang dengan Penataan Kawasan Cagar Budaya Banten Lama dan Kawasan Minapolitan serta Wisata Bahari di Kota Serang. Walaupun benyaknya rencana yang ditujukan kepada Pelabuhan Karangantu, hingga saat ini belum ada rencana detail akan Pelabuhan Karangantu.
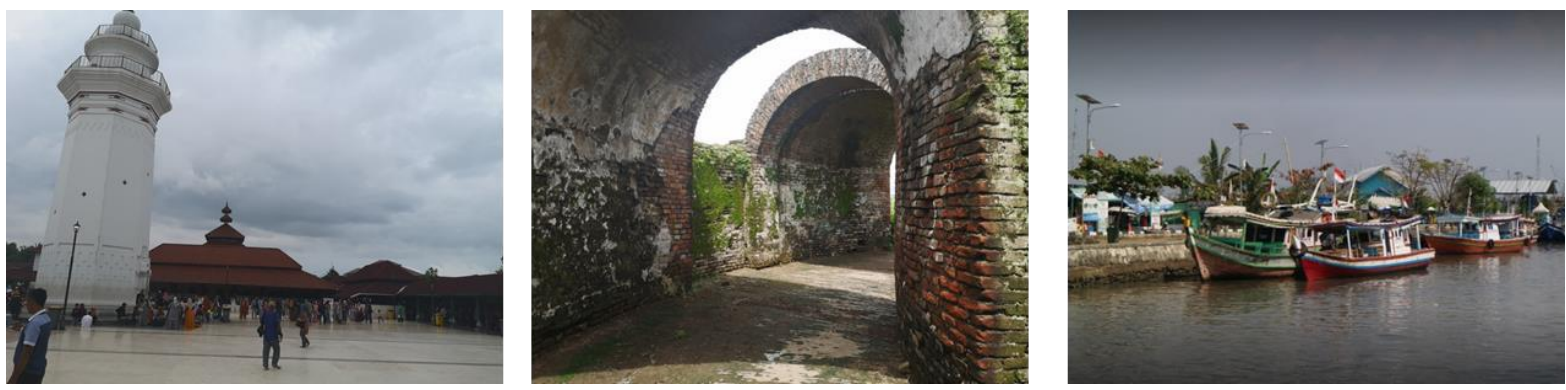

Gambar 1. Lokasi Penelitian Terhadap Kota Serang

Sumber: Hasil Olahan Penulis, 2020

Dalam bersaing di pasar pariwisata internasional, Indonesia melakukan banyak pembangun dalam bidang pariwisata di berbagai daerah dengan menonjolkan karakteristik masing-masing daerah, maka Banten pun harus ikut serta dalam perkembangan ini mengingat sejarah dan budaya menarik yang dimiliki oleh Banten Lama dan Pelabuhan Karangantu. Oleh sebab itu penulis ingin mencoba untuk melihat permasalahan dan potensi yang dimiliki oleh Banten Lama dan Pelabuhan Karangantu dalam usaha untuk mengintegrasikan Pariwisata Religi yang dimiliki Kawasan Cagar Budaya Banten Lama dengan Pariwisata Bahari di Pelabuhan Karangantu.

\section{Rumusan Permasalahan}

Masjid Agung Banten Lama, Istana Surosowan dan Pelabuhan Karangantu dahulu kala merupakan pusat kegiatan dan peradaban Kesultanan Banten. Selain berada di kawasan yang sama, ketiga objek bersejarah ini memiliki keterkaitan sejarah yang erat sehingga diperlukan adanya keterpaduan dari tiap objek bersejarah ini untuk saling mendukung dan memacu pariwisata di Kawasan Kota Banten Lama. Keterpaduan ini dalam bentuk integrasi antar potensi wisata yang dimiliki tiap objek yaitu potensi wisata religi yang dimiliki Masjid Agung Banten dan Istana Surosowan, dengan potensi wisata bahari yang dimiliki Pelabuhan Karangantu.

\section{Tujuan}

Tujuan dari penelitian ini sebagai berikut :

a. Mengidentifikasi kondisi fisik Kawasan Banten Lama dan Pelabuhan Karangantu untuk mengetahui permasalahan yang ada saat ini serta potensi wisata yang dapat dikembangkan.

b. Mengetahui tingkat konektivitas antara kawasan Banten Lama dan Pelabuhan Karangantu.

c. Memberikan usulan faktor-faktor yang dapat di integrasikan dari Wisata Reliji di Banten Lama dan Wisata Bahari di Pelabuhan Karangantu.

\section{KAJIAN LITERATUR}

\section{Integrasi Wisata}

Pengembangan pariwisata di suatu kota/daerah dapat lebih maksimal jika seluruh ODTW yang dimiliki suatu kota/daerah dikembangkan terintegrasi dan saling terkait. Jackson dan Murphy (2002) menjelaskan bahwa pengembangan pariwisata yang baik adalah yang memiliki kemampuan mengintegrasikan ODTW yanga ada dengan aspek penunjangnya terutama dengan kapabilitas pengelola dan stakeholders terkait untuk mengoptimalkan potensi wisata sehingga dapat membangun lingkungan yang nyaman untuk wisatawan terutama ketika wisatawan dalam perjalanan wisata. 
Integrasi wisata dalam pengembangannya perlu mewujudkan tujuan dari pariwisata kota yaitu memberikan kualitas hidup (quality of life) yang lebih baik untuk masyarakat lokal. Selain itu, pariwisata juga harus mampu memberikan kualitas kesempatan berusaha (quality of opportunity) untuk penyedia jasa dalam industri pariwisata, sehingga tercipta kualitas pengalaman (quality of experience) bagi wisatawan yang berkunjung (Postma, 2001). Dalam pengembangan pariwisata kota, selain amenitas (fasilitas rumah makan, penginapan dan lain lain) dan aksesibilitas (manajemen transportasi publik yang efektif), terdapat unsur auxiliary ( fasilitas tambahan) sebagai unsur pembentuk produk wisata kota yang optimal. Sehingga dibutuhkan model pengembangan wisata yang melibatkan masyarakat lokal dan sektor swasta yang berperan sebagai unsur auxiliary. Fungsi dari auxiliari adalah sebagai pengoperasi dan pengendali pengembangan pariwisata kota.

\section{Wisata Religi}

Salah satu bentuk dari Wisata Budaya adalah Wisata religi yang menurut Raj (2015) merupakan fenomena multipolar yang didorong oleh serangkaian motif dan mencakup unsur-unsur yang berbeda yang sulit untuk dimasukkan ke dalam skema yang terbentuk sebelumnya, tetapi menarik kembali aspirasi leluhur untuk mencapai hubungan dengan keilahian yang dijelaskan oleh tiap agama-agama dengan berbagai cara. Marpaung (2002), lebih lanjut menjelaskan bahwa, wisata keagamaan adalah jenis wisata yang erat kaitannya dengan wisatawan atau peziarah yang memiliki latar agama yang sama atau hal-hal pernah berhubungan dengan masa lalunya.

Dalam definisinya, terdapat perbedaan yang mendasar dari wisata religi dengan wisata pada umumnya. Fahey (2002) menjelaskan terdapat 7 elemen dasar yang berbeda dari antara wisata religi dengan wisata umumnya. Berikut rincian perbedaan dari tiap elemen.

Tabel 1. Perbedaan Wisata Religi dengan Wisata Umumnya

\begin{tabular}{cll}
\hline Elemen & \multicolumn{1}{c}{ Wisata Religi } & \multicolumn{1}{c}{ Wisata } \\
\hline Keimanan & $\begin{array}{l}\text { Selalu terkandung harapan } \\
\text { Keimanan }\end{array}$ & Tidak dibutuhkan \\
\hline Pertapaan & Mencari keutuhan iman & Tidak dibutuhkan \\
\hline Komunitas & Adanya rasa menyendiri & Adanya rasa kebersamaan \\
\hline Ruang Sakral & $\begin{array}{l}\text { Sepi digunakan untuk menciptakan ruang sakral } \\
\text { internal }\end{array}$ & Tidak ada \\
\hline Penawaran Nazar & $\begin{array}{l}\text { Meninggalkan sebagian “diri yang lalu”, belajar } \\
\text { untuk merelakan, mencari jalan hidup yang lebih } \\
\text { baik }\end{array}$ & Tidak ada \\
\hline Perayaan & $\begin{array}{l}\text { Kemenangan atas diri sendiri, merayakan untuk } \\
\text { mengenang }\end{array}$ & Berpesta untuk melupakan diri \\
\hline Ketekunan & $\begin{array}{l}\text { Munculnya rasa komitmen dan rasa bahwa ziarah } \\
\text { tidak pernah berakhir hingga ajal datang }\end{array}$ & Liburan akan berakhir \\
\hline
\end{tabular}

Sumber: Fahey, 2002

Salah satu karakteristik dari pengunjung situs keagamaan yaitu adanya kecenderungan bepergian dengan keluarga anggota atau kelompok terorganisir. Walaupun dilakukan secara bersama-sama, wisatawan atau peziarah cenderung melakukan wisata dengan raa menyendiri, mengisolasi diri untuk mencari ketenangan batin sehingga walaupun dilakukan bersama terkadang pengalaman yang dirasakan berbeda untuk setiap individu/ selain itu salah satu karakteristik dari wisata religi adalah perjalanan yang dilakukan sangat musiman, tidak hanya dipengaruhi oleh iklim dan cuaca, tetapi juga dengan terjadinya liburan suci, upacara, dan jadwal kerja.

\section{Wisata Bahari}

Definisi Pariwisata Bahari menutu Pendit (2003) adalah jnis pariwisata yang terkait dengan kegiatan olah raga air lebih-lebih baik di pantai, teluk atau lautan lepas seperti memancing, berlayar, menyelam 
sambil melakukan pemotretan, kompetisi selancar, mendayung dan sebagainya. Sedangkan menurut Sastrayuda (2010) Wisata Bahari adalah jenis pariwisata alternatif yang berkaitan dengan kelautan, baik di atas permukaan laut maupun kegiatan yang dilakukan di bawah permukaan laut. Berdasarkan kedua definisi tersebut dapat disimpulkan bahwa wisata bahari adalah semua kegiatan wisata yang menjadikan sumber daya alam daerah pesisir beserta semua potensinya sebagai daya tarik yang unik untuk dinikmati wisatawan.

Pariwisata bahari sendiri merupakan salah satu alternatif pariwisata berkelanjutan yang dimana bukan semata kegiatan memperoleh hiburan dari sumber daya alami lingkungan lautan dan pesisir serta daya tarik budaya, tetapi juga kegiatan di mana wisatawan diharapkan dapat berpartisipasi langsung mengembangkan konservasi lingkungan dan pemahaman mendalam tentang ekosistem lautan dan pesisir (Ismayanti, 2016). Adapun tujuan dari Wisata Bahari sendiri adalah:

a. Mengembangkan dan meningkatkan upaya memanfaatkan lingkungan alam pada umumnya dan lingkungan bahari pada khususnya sebagai sumber daya sosial dan ekonomi yang pengelolaannya tetap harus berwawasan lingkungan dan pembangunan berkelanjutan.

b. Memberikan gambaran mengenai pengelolaan wisata bahari secara tepat dan profesional, sehingga akan mampu mengembangkan adanya tuntutan konservasi dan menjaga kelestarian alam dengan mengikutsertakan peran serta masyarakat setempat guna membantu kesejahteraan masyarakat.

c. Mengkoordinasikan peran pihak-pihak yang berminat mengembangkan kawasan wisata bahari, di lingkungan wilayah setempat yang menjadikan wilayah tersebut sebagai salah satu daerah tujuan wisata bahari dengan melalui pola pengelolaan dalam bentuk corporate management.

Dalam pengembangannya, wisata bahari tidak memerlukan pembangunan sarana dan prasarana tertentu secara khusus karena wisatawan yang datang tertarik akan keindahan asli dari destinasi dan daya tarik wisatanya. Dalam pengembangan wisata bahari yang baik,pengembangannya harus memenuhi beberapa parameter tertentu. Parameter tersebut yaitu keaslian, keunikan (baik alami maupun buatan), langkah konservasi yang baik, tersedianya informasi yang memadai tentang destinasi wisata sebelum perjalanan dimulai, aksesibilitas dan sarana komunikasi yang baik, dan kesiapan sumber daya manusia yang ada (Prasiasa dan Hermawan, 2012).

Dalam pengembangannya, diperlukan kebijakan-kebijakan yang harus di perhatikan untuk mengurangi dampak negatif dari pengembangan objek wisata. Prasiasa dan Hermawan (2012) merinci kebijakan pengembangan wisata bahari yang perlu diperhatikan adalah sebagai berikut.

a. Pengembangan wisata bahari harus mengikuti kaidah-kaidah pembangunan berkelanjutan yang berwawasan lingkungan,

b. Pengembangan wisata bahari diarahkan pada pola pengembangan ekowisata atau wisata ramah lingkungan yang mengupayakan pemanfaatan lingkungan alam bahari sekaligus juga menyelamatkan lingkungan alam bahari tersebut,

c. Pengembangan wisata bahari harus ditujukan pada upaya meningkatkan pemerataan kesempatan, pendapatan, peran serta dan tanggungjawab masyarakat setempat yang terpadu dengan pemerintah dan dunia usaha.

\section{METODE}

\section{Lokasi Penelitian}

Lokasi penelitian adalah Kawasan Cagar Budaya Banten Lama dan Pelabuhan Karangantu di Kecamatan Kasemen, Kota Serang, Provinsi Banten seperti yang terlihat di Gambar 2. 


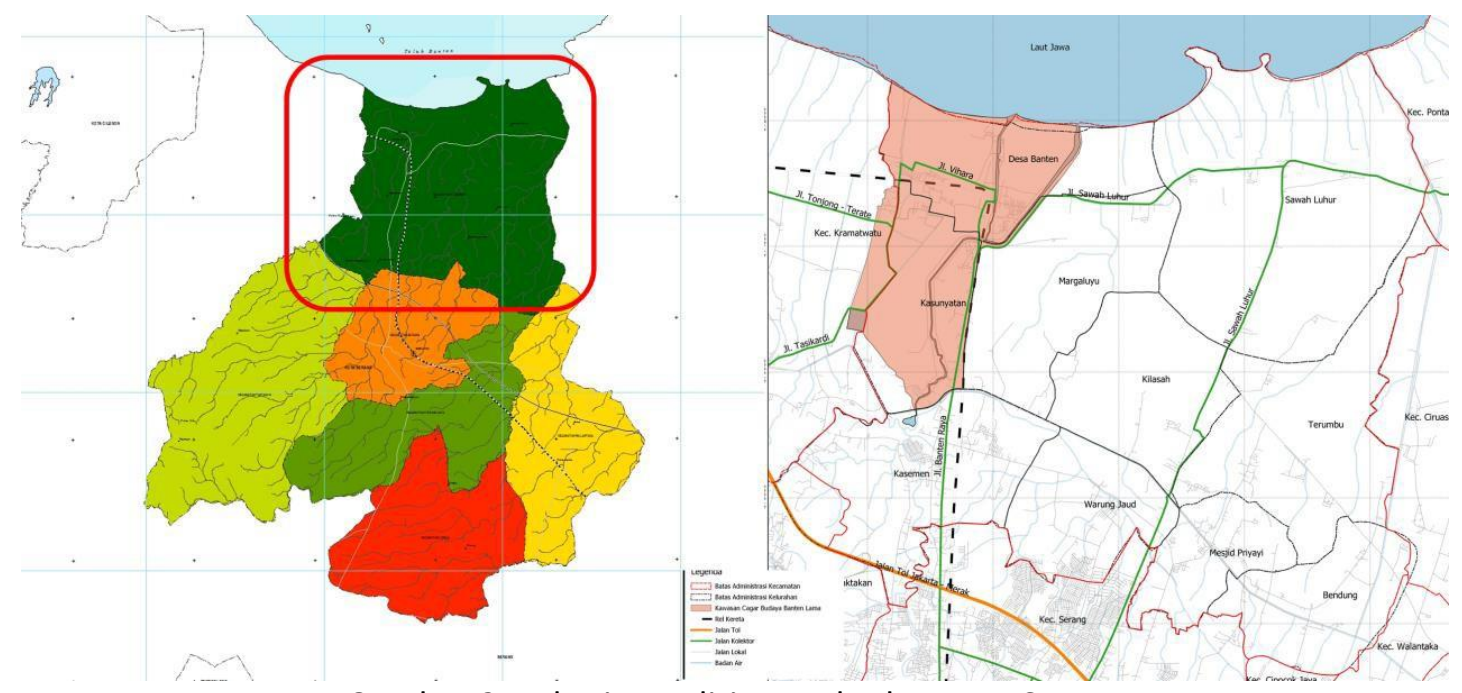

Gambar 2. Lokasi Penelitian Terhadap Kota Serang Sumber: Hasil Olahan Penulis, 2020

\section{Teknik Pengolahan Data}

\section{Analisis Kebijakan}

Analisis ini bertujuan untuk mengetahui kebijakan pemerintah dan deliniasi Kawasan Banten Lama dan Pelabuhan Karangantu yang terkait dengan Rencana Tata Ruang Wilayah Kota Serang, Rencana Detail Tata Ruang Kota Serang dan RIPPDA Kota Serang. Hal ini dilakukan untuk Dalam analisis ini untuk memilih peraturan yang sesuai dengan objek studi dan menjadi dasar legalitas.

\section{Analisis Lokasi dan Analisis Tapak}

Analisis Lokasi dilakukan untuk mengetahui karakteristik lokasi dari objek penelitian serta mengetahui potensi dan masalah yang ada disekitar kawasan yang dapat mempengaruhi penataan pada kawasan tersebut kedepannya. Analisis Tapak dilakukan untuk mengetahui karakteristik dari lahan yang menjadi objek penelitian seperti dimensi dan visual tapak, penggunaan lahan, hingga struktur ruang untuk kawasan tersebut.

\section{Analisis Nilai Sejarah}

Analisis nilai sejarah dilakukan berdasarkan hasil penelitian/temuan terdahulu tentang sejarah kawasan Banten Lama dan Pelabuhan Karangantu sehingga dapat dilakukan penilaian nilai historis yang dimilikinya.

\section{Analisis Daya Tarik Wisata Religius}

Analisis Potensi Wisata Religius dilakukan untuk mengetahui bagaimana kondisi wisata religi di Banten Lama dan seberapa besar daya tarik yang dihasilkan dari wisata religi yang ada terhadap wisatawan yang berkunjung di Kota Serang.

\section{Analisis Daya Tarik Wisata Bahari}

Analisis Potensi Wisata Bahari dilakukan untuk mengetahui kondisi dan kesesuaian aktivitas wisata bahari di Pelabuhan karangantu dan potensi daya tariknya untuk menjadi salah satu tujuan wisata di Kota Serang.

\section{Analisis Integrasi Wisata}

Analisis ini digunakan untuk mengetahui factor-faktor yang sesuai dalam mengembangkan pariwisata dengan mengintegrasikan daya tarik wisata Banten Lama dan daya tarik wisata Pelabuhan Karangantu. 


\section{Alat Analisis}

Alat analisis yang pakai dalam penelitian ini adalah metode deskriptif akan memperoleh gambaran tentang suatu hal dengan menggunakan data-data yang telah dikumpulkan dan kemudian menyajikannya dalam bentuk tabel maupun grafik. Tujuan dari alat analisis ini adalah data- data tersebut dapat disajikan dalam bentuk yang ringkas dan mudah dipahami.

\section{DISKUSI DAN HASIL}

\section{Analisis Kebijakan}

Analisis kebijakan yang penulis lakukan pada penelitian ini meninjau peraturan pemerintah kota dalam Rencana Tata Ruang Wilayah (RTRW) Kota, Rencana Induk Pengembangan Pariwisata (RIPPDA) dan Rencana Strategis (Renstra) Perikanan. Peninjauan ini dilakukan dalam rangka menggali dasar penerapan Kawasan Banten Lama dan Pelabuhan Karangantu serta melihat seberapa besar dukungan kebijakan pemerintah dalam mendukung aktivitas wisata yang terdapat di Kawasan Cagar Budaya Banten Lama.

Tabel 2. Hasil Analisis Kebijakan

\begin{tabular}{|c|c|}
\hline Aspek & Kondisi Eksisting \\
\hline \multicolumn{2}{|c|}{ RTRW Kota Serang } \\
\hline $\begin{array}{l}\text { Pengembangan wisata di Kasemen untuk pariwisata } \\
\text { religi dan budaya serta pariwisata alam. }\end{array}$ & $\begin{array}{l}\text { Pengembangan wisata di Kasemen meliputi Wisata } \\
\text { Religi dan Budaya d Kawasan Cagar Bduaya Banten } \\
\text { Lama dan Wlstaa Bahari di } \\
\text { Pelabuhan Karangantu }\end{array}$ \\
\hline
\end{tabular}

Pola Ruang Kawasan Cagar Budaya dan Ilmu

Pengetahuan di Kawasan Cagar Budaya Banten Lama

- Kawasan Perlindungan Setempat di sempadan pantai di Karangantu dan Sungai Cibanten

- Kawasan sawah beririgasi

- Kawasan perikanan tangkap di Pelabuhan Karangantu

- Kawasan budidaya perikanan air payau di Desa Banten

- Kawasan pengembangan pariwisata religi dan pariwisata lainnya di koridor utara, Kecamatan Kasemen

Kawasan Pelabuhan Karangantu diarahkan untuk mengembangkan dan mendukung penyediaan sarana dan prasarana penunjang; dan menyediakan ruangruang untuk golongan usaha skala kecil termasuk sektor informal dan ruang-ruang terbuka bersifat umum.

Kawasan Cagar Budaya Banten lama adalah
mendorong perkembangan/revitalisasi potensi wilayah yang belum dikembangkan secara optimal; mempertahankan delineasi kawasan Banten Lama; melestarikan dan menata fungsi-fungsi bersejarah dan budaya untuk mendukung kegiatan perdagangan jasa dan pariwisata dengan pengaturan sirkulasi yang dilengkapi dengan pedestrian yang nyaman; dan merelokasi kegiatan yang tidak sesuai dengan fungsi.
Saat ini tersedia ruang untuk pedagang kecil yang berjualan hasil olahan perikanan namun saat ini masih sedikit ruang terbuka untuk umum.

\footnotetext{
Saat ini masih daerah Masjid agung yang sudah direvitalisasi sedangkan beberapa daerah masih kekurangan fasilitas pendukung bahkan ada yang sudah tergerus nilai sejarahnya seperti Pelabuhan Karangantu dan Masjid Pecinan.
} 


\begin{tabular}{|c|c|}
\hline Aspek & Kondisi Eksisting \\
\hline \multicolumn{2}{|c|}{ RIPPDA KOTA SERANG } \\
\hline $\begin{array}{l}\text { Didalam Kaecamatan Kasemen sendiri ditetapkan dua } \\
\text { Destinasi paririwisata Daerah yaitu: } \\
\text { - Banten Lama dan sekitarnya sebagai tempat } \\
\text { wisata purbakala budaya, minat khusus, } \\
\text { pendidkan dan wisata kuliner; } \\
\text { - Pelabuhan Karangantu dan sekitarnya sebagai } \\
\text { kawasan minapolitan dan wisata bahari; }\end{array}$ & $\begin{array}{l}\text { Kecamatan Kasemen memeiliki dua destinasi yaitu } \\
\text { Kawasan Banten Lama dan Pelabuhan Karangantu } \\
\text { namun masih ada ketimpangan perkembangan } \\
\text { diantara keduanya dimana Kawsan Pelabuhan } \\
\text { Karangantu belum terlihat fungsi wisata baharinya } \\
\text { sehingga masih jarang wisatawana yang } \\
\text { berkunjung selain warga lokal. }\end{array}$ \\
\hline $\begin{array}{l}\text { Adapun strategi perencanaan pembangunan Banten } \\
\text { Lama terdiri dari: } \\
\text { - } \quad \text { pengaturan zonasi dan alur kunjungan } \\
\text { wisatawan yang jelas } \\
\text { - pelestarian cagar budaya dan aset lainnya yang } \\
\text { memiliki nilai sejarah; } \\
\text { - c.penataan dan pengembangan fasilitas parkir } \\
\text { terpadu; d.pembangunan infrastruktur dan } \\
\text { kelengkapan jalan e.penataan dan pengendalian } \\
\text { ruang untuk relokasi pedagang kaki lima serta } \\
\text { pembangunan pusat oleh- oleh dan cinderamata } \\
\text { khas Banten disekitar jalan kawasan wisata }\end{array}$ & $\begin{array}{l}\text { - Belum adanya alur wisata dan petunjuk wisata } \\
\text { yang baik sehingga banyak wisatawan yang tidak } \\
\text { tahu objek wisata lain di Banten Lama } \\
\text { - Masjid Pecinan dan Pelabuhan Karangantu tidak } \\
\text { terurus esehingga nilai sejarahnya berkurang } \\
\text { - Saat ini Banten Lama masih dalm Tahap } 1 \\
\text { Revitalisasi yang berfokus pada penataan } \\
\text { - kawasan sekitar Kompleks Masjid Agung } \\
\text { - Masih Banyaknya Pedagang yang }\end{array}$ \\
\hline \multicolumn{2}{|c|}{ RENSTRA PERIKANAN } \\
\hline $\begin{array}{l}\text { Fungsi Pelabuhan Karangantu sebagai Kawasan } \\
\text { Minapolitan dan Wisata Bahari }\end{array}$ & $\begin{array}{l}\text { Saat ini terdapat pusat pelelangan ikan, Hutan } \\
\text { Bakau dan Jasa penyebrangan ke pulau-pulau } \\
\text { disekitar Karangantu }\end{array}$ \\
\hline
\end{tabular}

Sumber: Hasil olahan penulis, 2020

Analisis Lokasi dan Analisis Tapak

Berdasarkan analisis lokasi yang penulis lakukan pada Kawasan Cagar Budaya Banten Lama, maka kesimpulan dan arahan yang didapat adalah sebagai berikut:

Tabel 3. Kesimpulan Analisis Lokasi

\begin{tabular}{|c|c|c|}
\hline Aspek & Kesimpulan & Rekomendasi \\
\hline Aksesibilitas & $\begin{array}{l}\text { - Memiliki akses pintu masuk Kawasan wisata } \\
\text { yang baik dengan adanya jalan Kolektor yang } \\
\text { melewati Kawsan Cagar Budaya Banten } \\
\text { Lama. } \\
\text { - Masih minimnya perjalanan melalui Stasiun } \\
\text { Karangantu } \\
\text { - Tidak adanya kejelasan dalam sistem } \\
\text { angkutan kota serang sehingga menyusahkan } \\
\text { aksesibilitas menggunakan transportasi } \\
\text { umum }\end{array}$ & $\begin{array}{l}\text { Diperlukan adanya peningkatan } \\
\text { kapasitas dan rute transportasi umum } \\
\text { di Kawasan Cagar Budaya Banten Lama }\end{array}$ \\
\hline Proximity & $\begin{array}{l}\text { - Adanya kedekatan dengan pusat-pusat } \\
\text { - kegiatan skala kota dan skala provinsi dan } \\
\text { akses yang baik kepada setiap pusat kegiatan } \\
\text { tersebut. } \\
\text { - Minimnya fasilitas pendukung wisata di } \\
\text { sekitar Kawasan Cagar Budaya Banten Lama }\end{array}$ & $\begin{array}{l}\text { Perlunya pembangunan fasilitas- } \\
\text { fasilitas pendukung di sekitar Kawasan } \\
\text { Cagar Budaya Banten Lama }\end{array}$ \\
\hline $\begin{array}{l}\text { Rencana } \\
\text { Infrastruktur } \\
\text { Makro }\end{array}$ & $\begin{array}{l}\text { - Adanya Rencana pengembangan Jalur Ring } \\
\text { Road Wilayah Utara Banten yang terhubung } \\
\text { Dengan Bandar Udara Soekarno Hatta }\end{array}$ & $\begin{array}{l}\text { Pemerintah telah menyadari potensi } \\
\text { yang dimiliki Kawasan Cagar Budaya } \\
\text { Banten Lama sebagai salah satu } \\
\text { Destinasi Wisata di Provinsi Banten. }\end{array}$ \\
\hline
\end{tabular}




\begin{tabular}{lll}
\hline Aspek & \multicolumn{1}{c}{ Kesimpulan } & \multicolumn{1}{c}{ Rekomendasi } \\
\hline & Terbukanya akses Kereta api baru ke Tanjung & Pemerintah saat ini harus berupaya \\
& Priuk & mewujudkan pembangungan sesuai \\
- Terbukanya Akses Baru dari dan ke Pulau & dengan rencana tata ruang yang telah \\
& Sumatra dengan adanya Jembatan Selat \\
& Sunda & di susun. \\
\end{tabular}

Sumber: Hasil olahan penulis, 2020

Selanjutnya berdasarkan analisis tapak yang penulis lakukan pada area Kawasan Inti Cagar Budaya Banten Lama dan Kawasan Pelabuhan Karangantu, maka kesimpulan dan rekomendasi yang didapat tertuang dalam Tabel 4 berikut.

Tabel 4. Kesimpulan Analisis Tapak

\begin{tabular}{|c|c|c|}
\hline Aspek & Kesimpulan & Rekomendasi \\
\hline $\begin{array}{l}\text { Penggunaan } \\
\text { Lahan }\end{array}$ & $\begin{array}{l}\text { Aktifitas wisata di Pelabuhan Karangantu rentan akan } \\
\text { gangguan dari aktifitas warga }\end{array}$ & $\begin{array}{l}\text { Perlu adanya penataan di } \\
\text { Kawasan Pelabuhan Karangantu } \\
\text { untuk mengurangi benturan } \\
\text { aktifitas di Kawasan Pelabuhan } \\
\text { Karangantu }\end{array}$ \\
\hline $\begin{array}{l}\text { Kondisi } \\
\text { Konektivitas }\end{array}$ & $\begin{array}{l}\text { Kondisi Konektivitas prasarana jalan antara Kompleks } \\
\text { Masjid Agung dan Kawasan Pelabuhan Karangantu } \\
\text { sudah cukup baik namun perlu adanya pembangunan } \\
\text { jalur pedestrian agar kedua kawasan lebih mudah } \\
\text { untuk diakses pejalan kaki. Sedangkam untuk } \\
\text { Konektivitas transportasi umum antara Kompleks } \\
\text { Masjid Agung dan Kawasan Pelabuhan Karangantu } \\
\text { masih belum baik sehingga warga banyak yang } \\
\text { menggunakan kendaraan pribadi ataupun menyewa } \\
\text { angkutan pariwisata. }\end{array}$ & $\begin{array}{l}\text { Perlu adanya penyediaan } \\
\text { angkutan umum pariwisata dan } \\
\text { pengembangan jalur pedestrian }\end{array}$ \\
\hline
\end{tabular}

Sumber: Hasil olahan penulis, 2020

\section{Analisis Nilai Sejarah}

Berdasarkan analisis nilai sejarah yang penulis lakukan pada area Kawasan Inti Cagar Budaya Banten Lama dan Kawasan Pelabuhan Karangantu, maka kesimpulan yang didapat tertuang dalam Tabel 5.

Tabel 5. Analisis Lokasi

\begin{tabular}{ll}
\hline Aspek & Kesimpulan \\
\hline Nilai Sejarah & Nilai sejarah dari Masjid Agung dan Istana Surosoan terbilang tinggi dimana keaslian \\
& dan keutuhannya masih tinggi dan juga didukung oleh fasilitas pendukungnya yang \\
& membuat okedua obejk ini semakin menarik Sedangkan dalam Pelabuhan Karangantu \\
& keutuhan dan keaslian pelabuhan rendah namun nilai sejarahnya masih tinggi \\
& dimana kedudukannya menjadi pelabuhan internasional pertama di pulau jawa.
\end{tabular}

Keterkaitan sejarah Adanya hubungan yang erat antara erkembangan Kota Banten lama dan Karangantu Banten Lama dan dimana walaupun bentuk kota semakin meluas lahan untuk fungsi Pelabuhan selalu Pelabuhan ada dan menjadi bagian yang tak terpisahkan dari Banten Lama.

Karangantu

Sumber: Hasil olahan penulis, 2020

\section{Analisis Daya Tarik Wisata}

Bila didasarkan dengan teori Yoeti (2008) tiga unsur. Pertama, something to see, yaitu daerah tersebut harus dapat dilihat dan disaksikan. Juga harus ada atraksi wisata yang berbeda dengan apa yang dimiliki oleh daerah lain. Atraksi wisata ini berupa Makam Sultan Maulana Hasanuddin berada di 
lingkungan Masjid Agung Banten Lama, makam keluarga kesultanan Banten, menara masjid Agung Banten Lama, dan Istana Surosowan. Kedua, something to do, yaitu lokasi wisata punya beberapa kegiatan yang dapat dilakukan sehingga wisatawan bisa betah berlama-lama untuk tinggal di lokasi tersebut. Ketiga, something to buy, yaitu daerah tersebut harus memiliki fasilitas berbelanja, khususnya barang-barang souvenir dari kerajian masyarakat lokal sebagai oleh-oleh untuk dibawa pulang.

Tabel 6. Hasil Analisis Daya Tarik Wisata

\begin{tabular}{|c|c|c|}
\hline Aspek & Banten Lama & Karangantu \\
\hline \multirow{2}{*}{$\begin{array}{l}\text { Something } \\
\text { To See }\end{array}$} & & 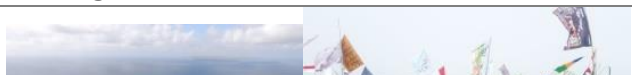 \\
\hline & $\begin{array}{l}\text { Atraksi wisata ini berupa Makam Sultan } \\
\text { Maulana Hasanuddin berada di lingkungan } \\
\text { Masjid Agung Banten Lama, makam keluarga } \\
\text { Kesultanan Banten, menara masjid Agung } \\
\text { Banten Lama, dan Istana Surosowan. } \\
\text { Sedangkan atraksi yang ada di Kesultanan } \\
\text { Banten antara lain Peringatan Maulid Akbar, } \\
\text { Khaul (memperingati hari kematian ulama), } \\
\text { dan Festival Surosowan. }\end{array}$ & $\begin{array}{l}\text { Pengunjung juga dapat menikmati } \\
\text { keindahan Pulau-pulau disekitar Karangantu } \\
\text { seperti Pulau Tiga, Pulau Empat dan Pulau } \\
\text { Lima. Sedangkan atraksi yang ada di } \\
\text { Pelabuhan Karangantu sendiri yaitu Festival } \\
\text { Nadran yang pernah berlangsung pada } \\
\text { Tahun 2017. }\end{array}$ \\
\hline \multirow[t]{2}{*}{$\begin{array}{l}\text { Something } \\
\text { To Do }\end{array}$} & & 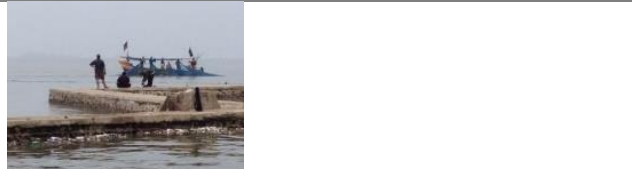 \\
\hline & $\begin{array}{l}\text { Kesultanan Banten memiliki kegiatan } \\
\text { yang bisa membuat peziarah melakukan } \\
\text { sesuatu, misalnya zikir dan mengaji di } \\
\text { hadapan makam Sultan Maulana Hasanudin, } \\
\text { melihat arsitektur masjid Agung Banten, } \\
\text { piknik dan berswafoto di alun-alun. }\end{array}$ & $\begin{array}{l}\text { Pelabuhan Karangantu sendiri memiliki } \\
\text { beberapa aktifitas wisata yang dapat } \\
\text { dilakukan oleh pengunjung yaitu aktifitas } \\
\text { memancing dan menyebrang ke pulau-pulau } \\
\text { di sekitar Karangantu. }\end{array}$ \\
\hline \multirow[t]{2}{*}{$\begin{array}{l}\text { Something } \\
\text { To Buy }\end{array}$} & & \\
\hline & $\begin{array}{l}\text { Kesultanan Banten menyediakan fasilitas } \\
\text { belanja berupa Pasar Tradisional Banten Lama } \\
\text { dimana Pengunjung bias membeli Hasil Alam } \\
\text { dan Souvenir Banten Lama. }\end{array}$ & $\begin{array}{l}\text { Di Pusat Pelelangan Ikan, Pengunjung dapat } \\
\text { langsung membeli hasil tangkapan Nelayan } \\
\text { yang masih segar. Selain itu terdapat juga } \\
\text { beberapa kios yang menjual hasil olahan } \\
\text { ikan berupa Kerupuk, lkan Asin dan } \\
\text { Bandeng. Selain pusat lelang, di Karangantu } \\
\text { juga terdapat pusat jajaanan dimana } \\
\text { pengunjung dapat menikmati berbagai } \\
\text { macam hidnagan laut hasil tangkapan } \\
\text { nelayan sekitar. }\end{array}$ \\
\hline
\end{tabular}

Sumber: Hasil olahan penulis, 2020 


\section{Analisis Integrasi Wisata}

Berdasarkan hasil analisis sebelumnya didapatkan 4 konsep integrasi yang dapat diterapkan untuk memadukan Objek Wisata Religi dan Objek Wisata Bahari. Berikut penjelasan setiap strategi yang dapat diterapkan.

\section{Integrasi Aksesibilitas}

Integrasi Aksesibilitas antar objek wisata dilakukan untuk menjawab permaslaahan aksesibilitas antar objek yang sulit karena tidak ada moda transportasi masal yang menuju ke tiap objek wisata, Sehingga pengunjung banyak yang mengendarai kendaraan pribadi untuk menuju setiap objek wisata. Pengunjung yang menggunakan kendaraan pribadi ke setiap objek wisata sulit mendapatkan tempat parkir dan akhirnya parkir di pinggir jalan. Dari permasalahan tersebut diperlukan penyediaan transportasi masal antar objek wisata. Penyediaan transportasi tersebut dapat berupa:

a. Kawasan Banten Lama memiliki lebar jalan 7 meter, dapat digunakan untuk menyediakan kendaraan pariwisata berupa mini bus, dan luas lahan parkir di Kawasan Banten Lama lebih dari 1 ha, dapat digunakan untuk terminal dan halte kendaraan antar pariwisata.

b. Setiap objek wisata Kawasan Banten Lama dikelilingi kanal, kanal tersebut digunakan untuk berpergian dan pertahanan oleh Kerajaan Banten. Kanal tersebut dapat di manfaatkan sebagai moda transportasi dengan menggunakan kapal kecil dan sampan.

c. Masyarakat sekitar Kawasan Banten Lama masih ada yang menggunakan kuda sebagai moda transportasi. Agar suasana Kerajaan Banten dapat tercipta kembali, maka moda transportasi delman bisa digunakan untuk menciptakan suasana Kesultanan Banten.

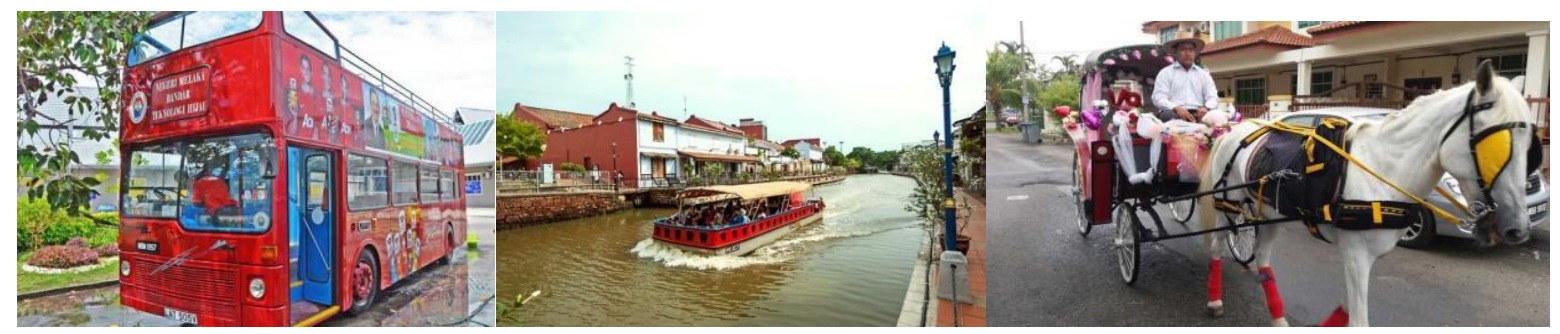

Gambar 3. Contoh Moda Transportasi yang Bisa Diterapkan

di Kawasan Banten Lama dan Karangantu

Sumber: Google.com

Dengan cara tersebut maka akan menghasilkan kemudahan aksesibilitas dan menambah estetika kawasan yang semakin bernuansa layaknya Kawasan Wisata. Dalam Penerapannya Pemerintah dapat melihat penerapannya di Kota Malaka sebagai referensi.

\section{Rekonstruksi Kesejarahan}

Berdasarkan analisis nilai sejarah, didapatkan bahwa objek sejarah Pelabuhan Karangantu banyak yang telah hilang bentuknya maupun kekhasannya. Padahal di puncak kejayaannya Pelabuhan ini menjadi tempat bertemunya berbagai etnis dan budaya baik lokal maupun internasional. Untuk meningkatkan daya tarik wisata di Pelabuhan ini, diperlukan adanya rekonstruksi kesejarahan di Kawasan Pelabuhan Karangantu.

Salah satu rekonstruksi yang dapat dilakukan adalah dengan mereplikasi kapal kesultanan. Dahulu di area Pelabuhan Karangantu terdapat Galangan Kapal Sultan. Di galangan ini kapal -kapal pribadi sultan dan kapal militer kesultanan berlabuh. Hasil replikasi ini nantinya bukan hanya menjadi pajangan tapi juga bisa difungsikan sebagai museum, tempat makan atau fungsi lain sesuai kebutuhan. Salah satu benchmark dari replikasi ini adalah Muzium Kemaritiman di Kota Malaka yang mereplikasi kapal dagang Kesultanan Malaka.

Saat ini Pelabuhan Karangantu tidak memiliki landmark yang dapat merepresentasikan Pelabuhan 
Karangantu dan memberi keterhubungan suasana antara Komplek Masjid Agung dan Karangantu. Hal ini dapat dilakukan dengan cara membangun monument yang bernuansa bahari dan budaya banten. Kapal Pinisi bisa menjadi contoh bentuk monument hal ini di dasarkan adanya jejak historis bermigrasinya Etnis Bugis Ke Banten Lama pada abad ke 17 dan hingga kini masih tersisa Perkampungan Bugis Di daerah Pelabuhan Karangantu. Dengan adanya Monumen dini diharapkan tidak hanya menambah estetika kawasan tapi juga menjadi Landmark Pelabuhan Karangantu.

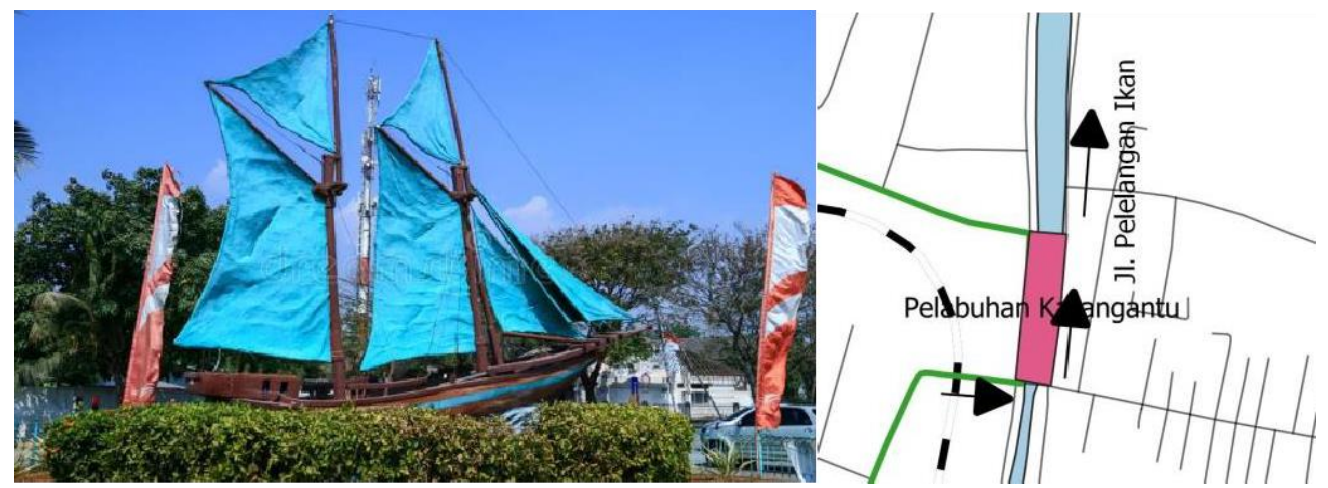

Gambar 4. Contoh Monumen Pinisi di Sunda Kelapa dan Rekomendasi Lokasi Monumen Sumber: Hasil Olahan Penulis, 2020

Selanjutnya rekonstruksi Pelabuhan Karangantu dapat juga berbentuk pembenahan ruang publik seperti jalur pedestrian, dermaga dan lain-lain Dalam rekonstruksi kesejarahan ruang publik yang dimiliki Pelabuhan Karangantu, unsur dari budaya Banten tak bisa dilepas dari segala kegiatan didalamnya, karena bukti sejarah telah menunjukkan bagaimana keterhubungan antara Kesultanan Banten dan Pelabuhan Karangantu. Keberadaan Kesultanan Banten, apabila diproyeksikan pada masa kini, merupakan unsur kepurbakalaan yang terpenting dalam pengembangan kawasan Banten Lama saat ini. Oleh sebab itu, Pelabuhan Karangantu tidak dapat lepas dari citra kawasan Banten Lama, dan harus memiliki hubungan kedekatan yang saling membutuhkan.

Selain hubungan tersebut, dalam sejarah, Kesultanan Banten sangat terkenal dengan aktivitasnya sebagai pusat perdagangan di Pulau Jawa. Sehingga segala peningkatan dalam unsur Pelabuhan Karangantu harus dikaitkan pada kegiatannya sebagai pusat perdaganga. Kualitas ruang publik yang terbentuk pun harus disesuaikan dengan gaya arsitektural kawasan Banten Lama, karena pelabuhan ini memiliki unsur sejarah yang sangat dekat hubungannya dengan Kesultanan Banten, keduanya harus dapat dilihat dalam sebuah sisi bersejarah, yaitu sebagai jejak Kesultanan Banten yang memiliki peran yang sangat penting pada masanya di Nusantara ini.

\section{Pengembangan Pelabuhan Karangantu sebagai Gerbang Wisata Bahari}

Berdasarkan analisis daya tarik wisata bahari didapatkan bahwa Pelabuhan Karangantu dijadikan sebagai titik awal bagi wisatawan yang ingin mengunjungi pulau Lima, Pulau Tiga dan pulau-pulau lain di Teluk Banten. Namun saat ini belum ada fasilitas terminal penumpang bagi kapal penyebrangan sehingga banyak penyedia fasilitas jasa penyebrangan yang menggunakan dermaga yang diperuntukkan untuk perahu nelayan.Dengan dipbangunnya terminal penumpang di pelabuhan karangantu bukan hanya memudahkan wisatawan yang ingin berkunjung ke pulau-pulau di Teluk Banten tapi juga bisa sebagai pusat penyedia jasa penyebrangan sehingga akses penyedia jasa penyebrangan ke calon penumpang mereka menjadi lebih mudah.

Selain itu, perlu juga peningkatan potensi wisata bahari yang dimiliki Pelabuhan Karangantu sendiri untuk menjadikan Pelabuhan Karangantu pelabuhan singgah yang mampu menyediakan atraksi wisata yang dibutuhkan oleh wisatawan pada saat melakukan transit. Saat ini Pelabuhan Karangantu memiliki daya tarik berupa Pusat Pelelangan Ikan dan Pujasera namun kondisinya saat ini masih belum ramah 
pada wisatawan. Di Pusat Pelelangan ikan pedagang masih berjualan di lantai sehingga banyak noda darah ikan di Lantai Pusat Pelelangan Ikan. Selain itu pedagang yang berjualan juga masih memakai system penyimpanan ikan yang sederhana hal ini menyebakan bau amis dari ikan masih tercium. Sedangkan di Pujasera Pelabuhan Karangantu, Pedagang-pedagang masih berjualan di gubuk dan terkadang masih terlihat banyak barang dagangan yang kurang higiernis. Dengan peningkatan kedua fasilitas ini diharapkan mampu menjawab permasalahan yang ada sehingga menarik wisatawan untuk berkunjung.

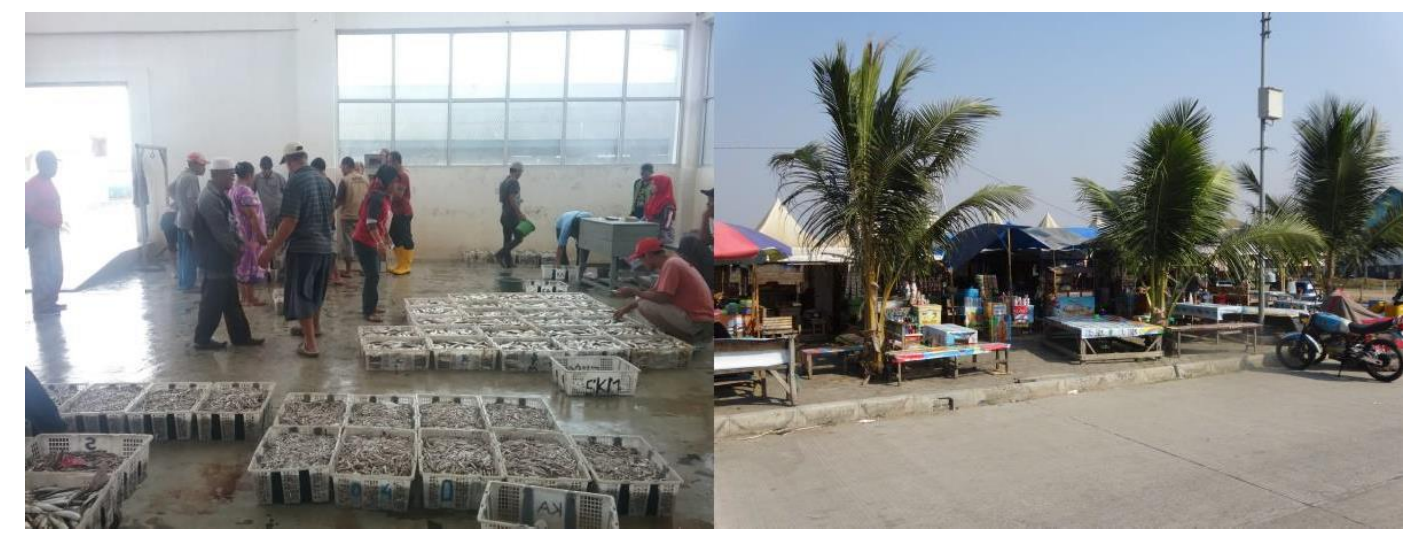

Gambar 5. Kondisi Eksisting Tempat Pelelangan Ikan (TPI) Karangantu dan Pujasera Sumber: Hasil Dokumentasi Penulis, 2020

\section{Integrasi Paket Wisata}

Di dalam integrasi ini, Pelabuhan Karangantu dipadukan dengan objek-objek wisata sejarah dan relligi yang ada di Kawasan banten Lama. Letak Pelabuhan Karangantu yang dekat dengan Pintu masuk Kawasan Cagar Bduaya Banten Lama dan banyaknya tempat makan hidangan laut cocok untuk menjadi tempat istirahat dan piknik wisatawan sebelum pulang kembali ke tempat tinggalnya. Adapun Alur perjalan pariwisata di Kawasan Banten Lama yang penulis rekomendasikan seperti pada Gambar 6 berikut.

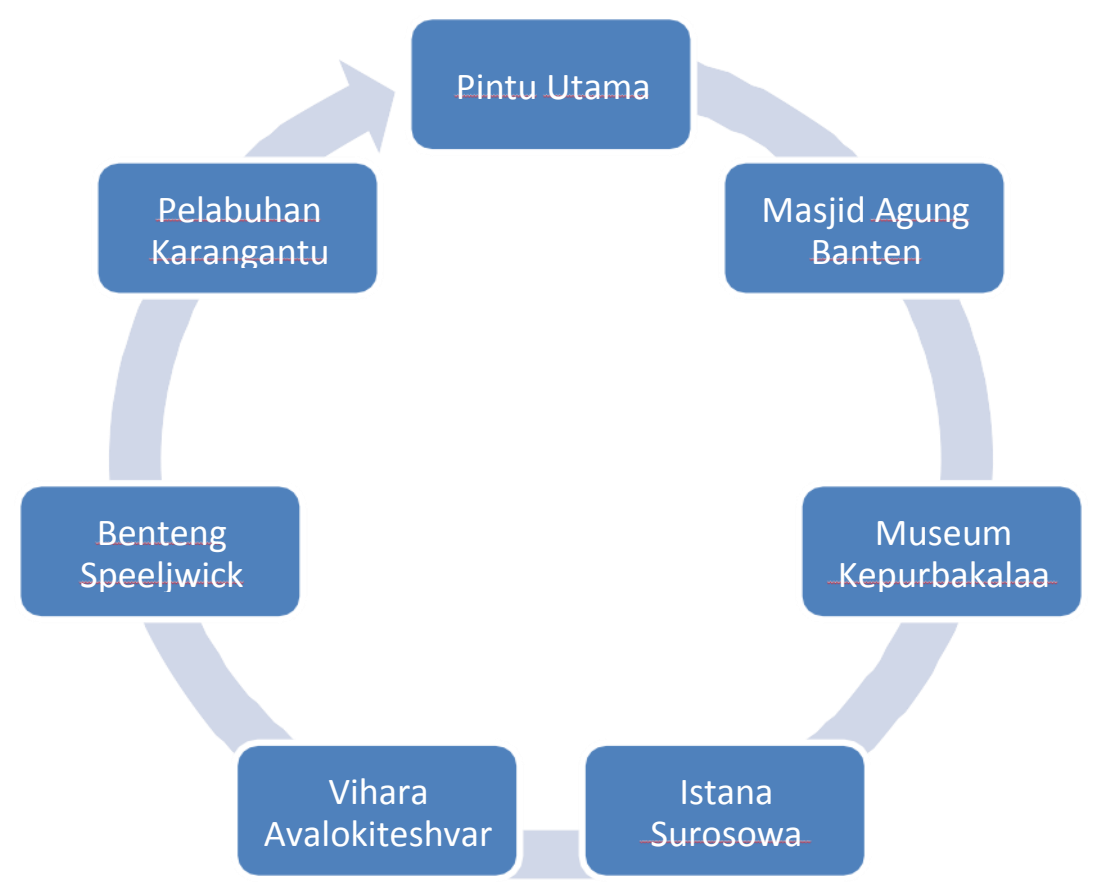

Gambar 6 Alur Perjalanan Pariwisata Kawasan Banten Lama Sumber: Hasil Olahan Penulis, 2020 
a. Pengunjung yang datang ke Kawasan Banten Lama memarkir kendaraannya di tempat parkir Kompleks Masjid Agung Banten yang telah disediakan, kemudian pengunjung membeli tiket masuk.

b. Pengunjung dari parkiran lalu langsung menuju Masjid Agung Banten untuk berziarah dan menikmati keindahan masjid dan alun-alunnya

c. Setelah mengunjungi masjid, pengunung berjalan kaki menuju Museum Situs Kepurbakalaan untuk melihat sejarah dari Kesultanan Banten.

d. Setelah mengunjungi museum Pengunjung berjalan kaki menuju Keraton Surosowan untuk menikmati atraksi budaya tari Katuran dan menikmati keindahan keraton, di Keraton Surosowan lalu pengunjung dapat menikmati mengunjungi Pasar Banten Lama untuk membeli Souvenir maupun jajanan.

e. Setelah mengunjungi Istana Surosowan. pengunjung menaiki transportasi umum pariwisata untuk menuju Vihara Avalokitesvara, di vihara pengunjung bisa menikmati keindahan vihara dan atraksi budaya cina.

f. Setelah mengunjungi vihara pengunjung menaiki transportasi umum pariwisata untuk menuju Benteng Speelwijk. disini pengunjung dapat menikmati taman di Benteng Speelwijk dan mempelajari sejarah VOC di tanah Banten.

g. Setelah mengunjungi Benteng Speelwijk pengunjung menaiki Transportasi Umum Pariwisata untuk menuju Pelabuhan Karangantu, di Pelabuhan Karangantu pengunjung bisa bersantai menikmati sunset, menikmati restoran atau tempat makan yang telah tersedia dan pengunjung juga dapat membeli oleh-oleh khas Kawasan Banten Lama

h. Setelah mengunjung Pelabuhan Karangantu pengunjung kembali ke area parkiran dan pulang ke tempat tinggal masing-masing.

\section{KESIMPULAN DAN SARAN}

\section{Kesimpulan}

Berdasarkan kondisi eksisting, terdapat potensi masalah di Kawasan Cagar Budaya Banten Lama yaitu ketimpangannya pembangunan antara Kompleks Masjid Agung dan Pelabuhan Karangantu, fasilitas akomodasi pariwisata belum disediakan dan pembangunan fasilitas pendukung pariwisata tidak merata, dan aksesibilitas antar objek wisata yang sulit. Lokasi Karangantu yang terletak 2,6 km dari Kompleks Masjid Agung ditambah dengan ketiadaannya moda transportasi umum membuat kedua objek wisata ini tidak terhubung dengan baik. Sehingga untuk menghubungkan kedua objek ini dibutuhkan daya tarik yang kuat dari Pelabuhan Karangantu dan aksesibilitas yang lebih baik antar kedua objek wisata. Dari penelitian ini ditemukan strategi integrasi Pelabuhan Karangantu dengan objek wisata religi di Kompleks Masjid Agung yaitu Integrasi Aksesibilitas, Rekonstruksi Kesejarahaan Pelabuhan Karangantu, Pengembangan Pelabuhan Karangantu sebagai Gerbang Wisata Bahari, dan Integrasi Paket Wisata.

\section{Saran}

Adapun Rekomendasi yang penulis berikan untuk Kawasan Banten Lama dan Pelabuhan Karangantu sebagai berikut:

a. Meningkatkan pariwisata terpadu dengan memudahkan aksesibilitas antar objek wisata dengan cara menambahkan moda transportasi khusus pariwisata. Dan juga penyediaan fasilitas akomodasi sehingga dapat memberikan kesempatan untuk pengunjungberwisata lebih lama

b. Melakukan replikasi atau membuat tiruan bangunan yang merepresentasikan sejarah kesultanan Banten di Pelabuhan Karangantu sebagai upaya untuk meningkatkan daya tarik Pelabuhan Karangantu

c. Meningkatkan fasilitas wisata bahari di Pelabuhan Karangantu dengan membuat terminal penumpan dan meningkatkan fasilitas Tempat Pelelangan Ikan dan Pujasera

d. Mengembangkan paket wisata Kawasan Banten Lama yang terpadu dimana Pelabuhan Karangantu berperan sebagai titik rekreasi wisatawan sebelum pulang ke tempat tinggalnya. 


\section{REFERENSI}

Fahey, F. (2002). Pilgrims or Tourists? The Furrow Vol. 53(4)

Ismayanti. (2016). Pariwisata Berkelanjutan dan Pengembangan Pariwisata Bahari. Jejak Bahari.

Jackson,J \& Murphy, P. (2002). Tourism Destinations as Clusters Analytic Experiences. The New World Tourism and Hospitality Research, 1: 36-53

Marpaung, H. (2002). Pengetahuan Kepariwisataan. Bandung: Alfabeta.

Pendit, N. (1994). Ilmu Pariwisata: Sebuah Pengantar. Jakarta: Pradnya Paramita,

Postma, A. (2001). An approach for integrated development of quality tourism. Paper presented at the ATLAS 10th Anniversary Conference. Dublin.

Prasiasa, D, \& Hermawan, H. (2012). Pengembangan Wisata Bahari di Indonesia. Jakarta: Pusat Penelitian dan Pengembangan Kebijakan Kepariwisataan

Raj, R. (2015). Religious Tourism and Pilgrimage Management: An International Perspective. Britania Raya: CAB

Sastrayuda, G. (2010). Konsep Pengembangan Kawasan Ekowisata. Yogyakarta: UPI. 
